\title{
Effect of post-welding heat treatment on wear resistance of cast-steel die with surfacing layer
}

\author{
Wujiao Xu*, Xin Ma, Nongjie Tang, Li Zhu, Wuhua Li, and Yongfeng Ding \\ College of Material Science and Engineering, Chongqing University, Chongqing 400044, PR China
}

Received 25 September 2015 / Accepted 8 October 2015

\begin{abstract}
The wear resistance capability of die surfacing layer under different Post-Welding Heat Treatments (PWHT) was analysed by Finite Element (FE) simulation and experiments. Taking hot forging process of a crankshaft as an example, a wear model of the hot forging die coated with surfacing layer was established using FE software DEFORM-3D. The simulation results indicated that the wear resistance capability of the die surfacing layer is optimal when tempering temperature and holding time are $550{ }^{\circ} \mathrm{C}$ and $4 \mathrm{~h}$ respectively. To verify the wear computational results, 16 groups of PWHT orthogonal wear tests were performed at a temperature of $400{ }^{\circ} \mathrm{C}$, which is a similar temperature to that occurs in an actual hot forging die. The wear-test result showed a good agreement with the FE simulation. SEM observation of the wear debris on 16 specimens showed that oxidative wear is dominant when the temperature was in $400{ }^{\circ} \mathrm{C}$. Furthermore, when tempering temperature and holding time were $550{ }^{\circ} \mathrm{C}$ and $4 \mathrm{~h}$ respectively, the carbide alloy dispersively distributes in the metallographic structure, which helps to improve the wear resistance of the surfacing layer.
\end{abstract}

Key words: Post-welding heat treatments, Surfacing layer, Wear resistance capability, Finite Element (FE) simulation

\section{Introduction}

In a hot forging process, complex loading conditions often lead to several types of die failures such as wear, plastic deformation, fatigue, etc., among which wear accounts for $70 \%$ of all the hot-forging die failures [1]. The lifespan of hot forging dies is one of the most important concerns in hot forging. From a economic point of view, accurate prediction of the die service life and extending it as much as possible are of significant importance to forging industry.

At present, closed-die forging processes are being developed towards large-scale, high-precision and high quality production. For heavy forgings, the corresponding hot-forging dies are normally very large. Traditionally, a hot-forging die may be made into an integral part made of a hot working steel. For this type of the die, the strength of die-cavity surfaces may be improved through PVD, PACVD, CVD coatings and diffusion processes such as Nitriding, in order to extend the service life of the die [2-5]. However, the cost per unit workpiece for such a die remains very high due to the high cost on the die material and on heat treatment.

For the production of heavy forgings, it has been proposed to apply the Functionally Graded Material (FGM) for manufacturing dies [6]. Considering the requirement of a hot forging process and the need to reduce the die cost, die construction with casting-steel substrate coated with the surfacing layer was adopted, as illustrated in Figure 1.

Since wear is the predominant factor affecting the die life in hot forging, the concept of the hot forging cast-steel die coated with the surfacing layer could be a useful solution. To effectively support the development of such a die, in-depth understanding of the die-wear would be needed.

Die-wear related topics such as wear mechanisms, wear modelling, prediction of die life, wear resistance, etc., have been subjected to intensive research in the past and recently. Archard wear model has been applied to the prediction of tool life in hot forging process, as a general purpose model [7]. Painter et al. developed a numerical simulation approach to predict wear and then optimized the process [8]. Schaefer predicted the tool wear with consideration of the changes of the hardness in the tool surface-layer [9]. Taking the deviation of the temperatures in preheated billets into consideration, Kim and Kang used a finite element method to study wear and plastic deformations of the dies [10]. Abachi et al. analysed the die wear in hot forging by a finite volume method, based on which a value of wear coefficient was recommended [11].

\footnotetext{
*e-mail: xuwujiao_cq@163.com
} 


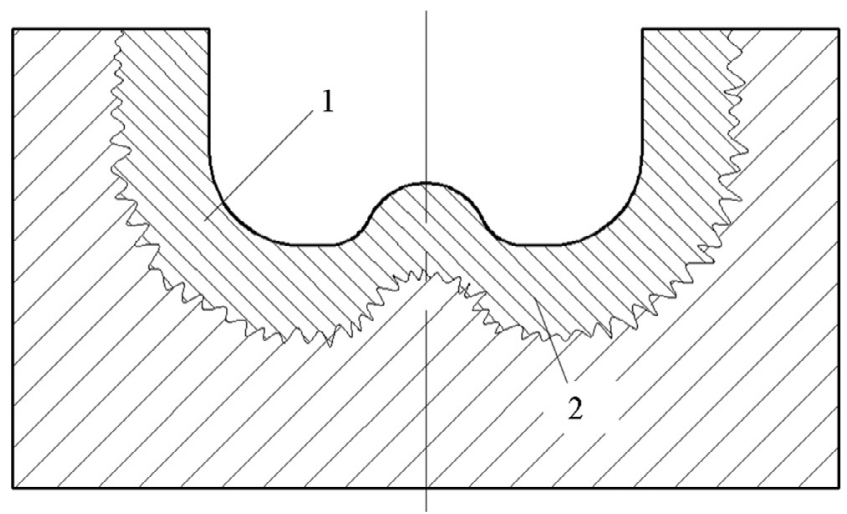

Figure 1. The schematic of a hot-forging cast-steel die coated with the surfacing layer: 1 - the surfacing layer, 2 - the casting-steel.

In this paper, besides the analysis of die-wear through $\mathrm{FE}$ modelling, analysis of the wear resistance capability of the die surfacing layer subjected different Post-Welding Heat Treatments (PWHT), are reported.

\section{The die material}

To study the wear resistance of a hot forging cast-steel die coated with surfacing layer, gas metal arc welding with $545 \mathrm{E}$ flux cored wires was used in surfacing welding. The cast-steel substrate was made of $\mathrm{ZG} 25 \mathrm{MnCrNiMo}$. 545E flux cored wires were utilized in the surfacing process. The dimensions of the die-block were $600 \mathrm{~mm} \times 380 \mathrm{~mm} \times 190 \mathrm{~mm}$.

To ensure reliability of the forging die, thickness of the surfacing layer should not be less than $20 \mathrm{~mm}$. At least 10 layers were created in the welding process, in which the thickness of each layer was about $2 \mathrm{~mm}$. Oxide skin and welding slag on the surface were removed after every surfacing layer was added. The welding current and voltage were $130 \mathrm{~A}$ and $26 \mathrm{~V}$ respectively. The welding velocity was set to be $180 \mathrm{~mm} \mathrm{~min}^{-1}$ and the welding inter-pass temperature was chosen to be $300 \pm 20^{\circ} \mathrm{C}$. Before welding the substrate was preheated to $350 \pm 25^{\circ} \mathrm{C}$. Chemical compositions for casting-steel substrate (ZG25MnCrNiMo) and surfacing layer (545E) are shown in Table 1 and the mechanical properties listed in Table 2.

The post-welding heat treatment, i.e. tempering process was carried out in an induction heating furnace. For 16 groups of orthogonal experiment, selected tempering temperatures were $420{ }^{\circ} \mathrm{C}, 480{ }^{\circ} \mathrm{C}, 550{ }^{\circ} \mathrm{C}, 600{ }^{\circ} \mathrm{C}$ and holding times $1 \mathrm{~h}, 2 \mathrm{~h}, 4 \mathrm{~h}$ and $6 \mathrm{~h}$ respectively.

To predict the wear of the cast-steel dies coated with surfacing layers under different PWHT, it is essential to establish constitutive relationships of the surfacing layers under various PWHT. To gain the constitutive relationships for the 16 groups of the experiment, a series of high temperature $\left(250{ }^{\circ} \mathrm{C}\right.$, $\left.300{ }^{\circ} \mathrm{C}, 350{ }^{\circ} \mathrm{C}, 400{ }^{\circ} \mathrm{C}, 450{ }^{\circ} \mathrm{C}\right)$ compression tests were carried out on a Gleeble thermo-mechanical simulator (Gleeble 3500 , heating rate: $10{ }^{\circ} \mathrm{C} / \mathrm{s}$, holding time: $150 \mathrm{~s}$ and amount of compression: $8 \%$ and strain rate: $0.0001 \mathrm{~s}$ ) which are shown

Table 1. Chemical composition of the casting-steel substrate and surfacing layer (wt.\%).

\begin{tabular}{lcccccccccc}
\hline \multicolumn{1}{c}{ Chemical composition } & $\mathrm{C}$ & $\mathrm{Si}$ & $\mathrm{Mn}$ & $\mathrm{P}$ & $\mathrm{S}$ & $\mathrm{Cr}$ & $\mathrm{Ni}$ & $\mathrm{Mo}$ & $\mathrm{Cu}$ & $\mathrm{Fe}$ \\
\hline ZG25MnCrNiMo (casting steel substrate) & 0.27 & 0.53 & 1.37 & 0.02 & 0.01 & 0.55 & 0.43 & 0.27 & 0.10 & 97.57 \\
545E (surfacing layer) & 0.10 & 0.77 & 0.83 & 0.008 & 0.007 & 11.32 & 2.12 & 2.43 & - & 82.42 \\
\hline
\end{tabular}

Table 2. The mechanical properties of the casting-steel substrate and surfacing layer.

\begin{tabular}{|c|c|c|c|c|c|}
\hline Die material & $\begin{array}{c}\text { Young modulus } \\
E(\mathrm{GPa})\end{array}$ & Poisson ratio $v$ & $\begin{array}{c}\text { Hardness } \\
\text { (HRC) }\end{array}$ & $\begin{array}{l}\text { Coefficient } \\
\text { of friction }\end{array}$ & $\begin{array}{l}\text { Yield stress } \\
\sigma_{0.2}(\mathrm{MPa})\end{array}$ \\
\hline ZG25MnCrNiMo (casting steel substrate) & $42.5 \pm 1.6$ & $0.3 \pm 0.016$ & $24 \pm 0.7$ & - & $512 \pm 12.1$ \\
\hline $545 \mathrm{E}$ (surfacing layer) & $27.6 \pm 0.9$ & $0.3 \pm 0.021$ & $48 \pm 1.2$ & $0.2 \pm 0.019$ & $588 \pm 15.3$ \\
\hline
\end{tabular}
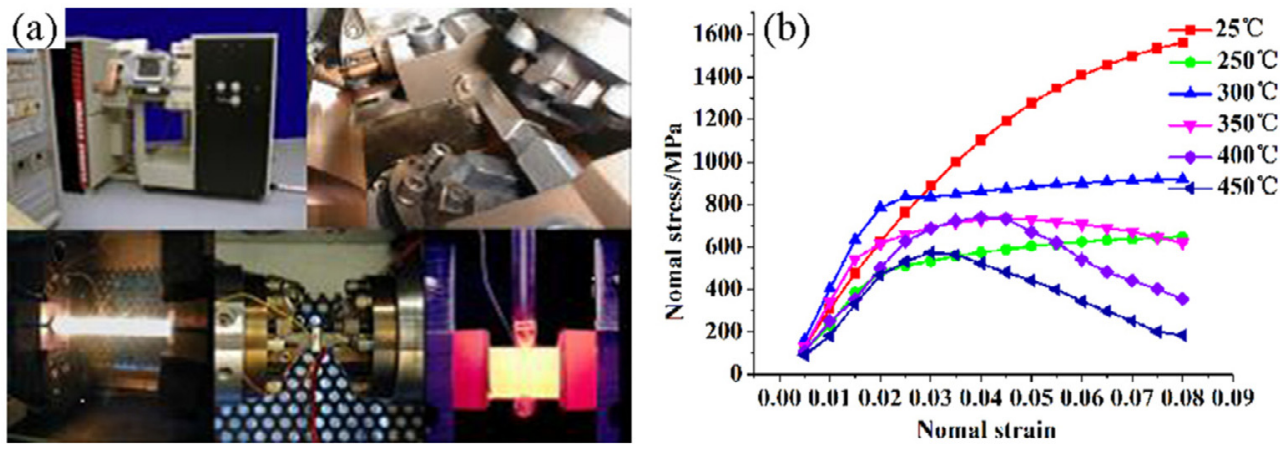

Figure 2. (a) The Gleeble thermo-mechanical simulator; (b) the constitutive relationship of the surfacing layer in different temperatures when the PWHT was carried out at $550{ }^{\circ} \mathrm{C}$ and $4 \mathrm{~h}$. 
Table 3. The main parameters used in FE simulation.

\begin{tabular}{cc}
\hline Parameters & Value \\
\hline Billet material & AISI-5140 \\
Billet initial forging temperature & $1150{ }^{\circ} \mathrm{C}$ \\
Die initial-temperature & $250{ }^{\circ} \mathrm{C}$ \\
Coefficient of heat convection & $0.02 \mathrm{~N} / \mathrm{s} \mathrm{mm}{ }^{\circ} \mathrm{C}$ \\
Radiation coefficient & 0.3 \\
Contact-surface heat transfer coefficient & 5 \\
Machine-ram speed speed & $280 \mathrm{~mm} / \mathrm{s}$ \\
Displacement increment & $1 \mathrm{~mm}$ \\
\hline
\end{tabular}

in Figure 2a. One group of the constitutive relationships whose tempering temperature and holding time were $550{ }^{\circ} \mathrm{C}$ and $4 \mathrm{~h}$ respectively are shown in Figure $2 \mathrm{~b}$. This was then, late, applied to the establishment of the wear model through using DEFORM-3D analysis software.

\section{Wear computation and experimental verification}

\subsection{The wear model established through DEFORM-3D}

To study the wear behaviour of the hot forging cast-steel die coated with surfacing layer, the hot forging of a crankshaft was analysed as a study case. For this crankshaft, there were two operations involved in the hot forging, namely the preforging and the finish forging. Using DEFORM-3D, a coupled thermo-mechanical simulation of the crankshaft forging was carried out. The main parameters of the simulation are listed in Table 3.

The Archard wear model, expressed in equation (1), was adopted to simulate the wear behaviour of the surfacing layer:

$$
d w_{i}=\int K \frac{P_{i}^{a} v_{i}^{b}}{H^{c}} \mathrm{~d} t
$$

where $d w$ is the wear depth of the die cavity, $P$ and $v$ the contact pressure and relative sliding velocity respectively.
Generally $a$ and $b$ are set as 1 , and $c$ equals to 2 for the simulation of the tool steels as the tool-material [7]. $H$ is hardness of the tool material and $\mathrm{d} t$ the time increment. $K$ is wear coefficient and the subscript $i$ refers to the surface node on the forging die. The effect of the different PWHT on the constitutive relationship of the surfacing layer was considered when calculating the wear depth.

The simulated finished forging and the die model shown in Figure 3a. After the wear calculation was completed, the weardepth distribution in the forging-die cavity was displayed (Figure 3b). It can be observed that the area having severe wear in the die cavity appears at the cavity for the forming of the crankshaft front-end (the wear corresponding to the flash land was not considered in the analysis reported in this paper). The field distributions of the crankshaft can be seen in Figure 4. It can be seen that the severe wears occur in those zones where the contact pressure, the velocity and the temperature were higher.

Due to that the severely worn area was at the die-cavity section where forming the crankshaft front-end took place, the section A-A was chosen to be focused for the study of the effect of PWHT on the wear depth of the surfacing layer. The circumferential coordinate system defined to illustrate the wear depth in the section A-A is shown in Figure 3c.

Figure 5 shows the computed wear-depth along the section A-A in the forging die with different PWHTs (including different tempering temperatures and holding time). Among the 16 combinations of the PWHT conditions, the optimal tempering temperature and holding time were found to be $550{ }^{\circ} \mathrm{C}$ and $4 \mathrm{~h}$ respectively. Under this PWHT condition the die wear-depth peak (shown in the circumferential coordinate system) in section A-A, in a single forging cycle, was $9.92 \times 10^{-5} \mathrm{~mm}$, which is shown in Figure 7a.

\subsection{Wear test}

The wear-resistant plate material and pressure-head material used in the wear test are 545E and AISI-5140 receptively, which are the same kinds of the materials for the surfacing (a)

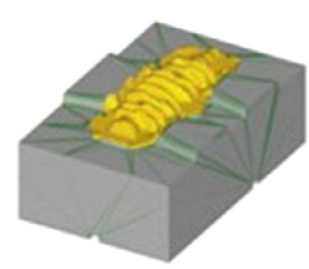

(c)

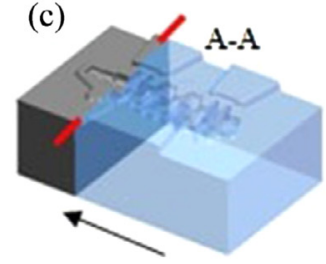

(b)

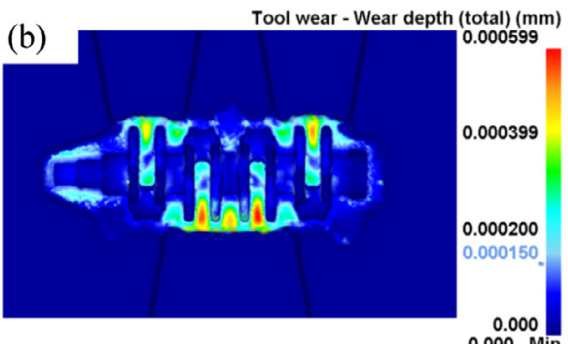

0.000 Min

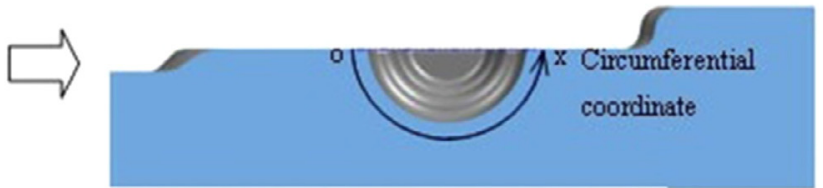

Figure 3. (a) The finish forging of the crankshaft; (b) wear depth distribution of the crankshaft; (c) circumferential coordinate system of the section A-A. 
(a)

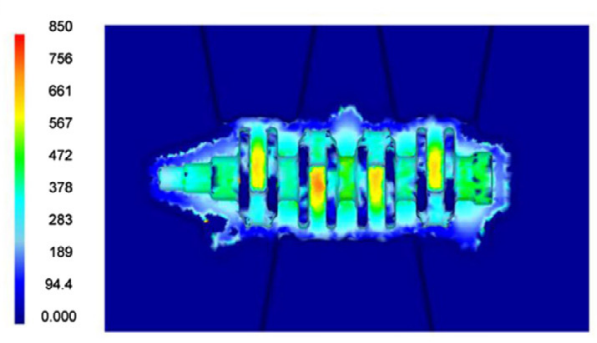

(b)

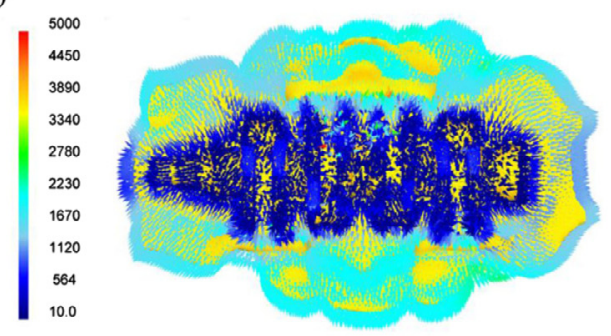

(c)

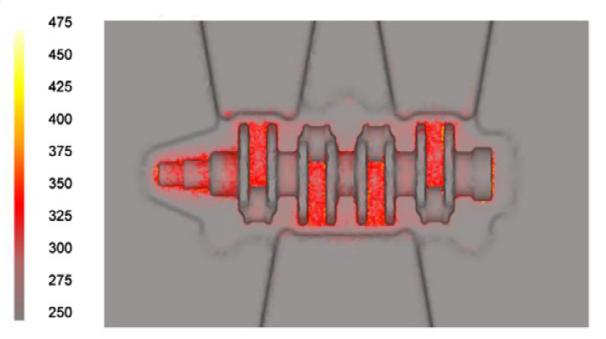

Figure 4. Results of the FE Simulation of crankshaft forging: (a) Contact pressure distribution (MPa); (b) Velocity distribution (mm/s); (c) Temperature distribution $\left({ }^{\circ} \mathrm{C}\right)$.

(a)

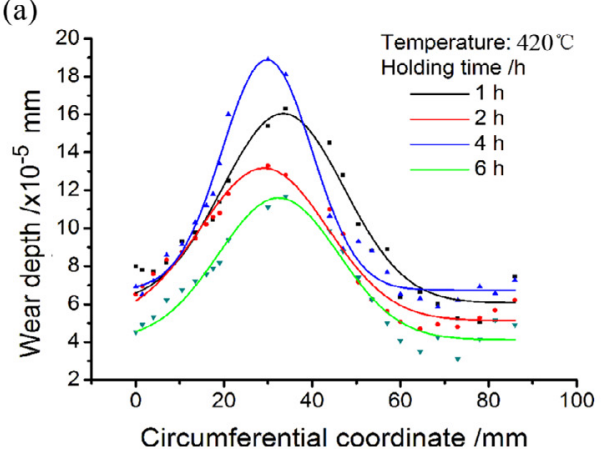

(c)

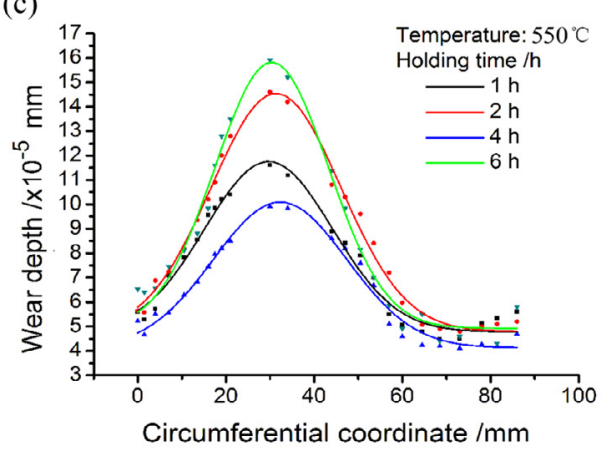

(b)

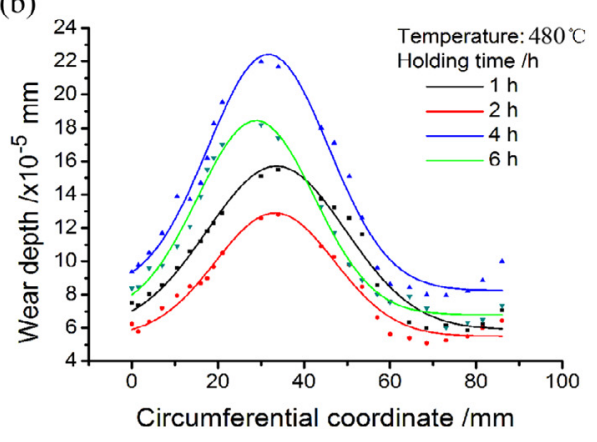

(d)

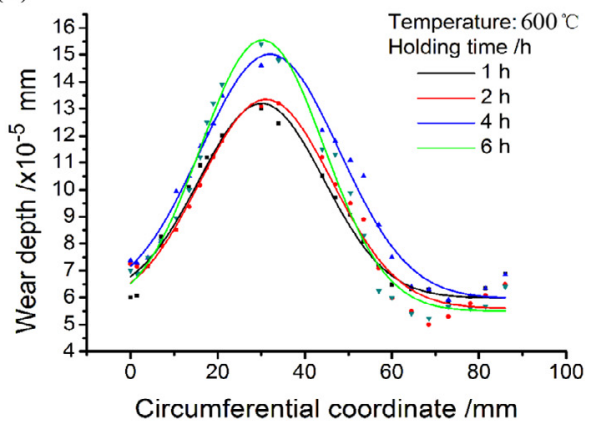

Figure 5. The computed wear-depth of the section A-A in the forging die with the tempering temperature of: (a) $420{ }^{\circ} \mathrm{C}$, (b) $480{ }^{\circ} \mathrm{C}$, (c) $550{ }^{\circ} \mathrm{C}$ and (d) $600{ }^{\circ} \mathrm{C}$.

layer and the billet that were used in the forging test respectively. The applied contact force and relative sliding velocity used in the wear test were similar to that obtained from the FEM simulation of crankshaft hot forging. The wear test was carried out on an HSR-2 M wear-testing machine (temperature: $400{ }^{\circ} \mathrm{C}$; force: $50 \mathrm{~N}$, speed: $400 \mathrm{r} / \mathrm{min}$; time: $3 \mathrm{~min}$; and length: $5 \mathrm{~mm}$ ). Figure 6 shows the HSR-2 M wear-testing machine and the friction pairs used in the wear test.
To verify the wear calculation result presented in Figure 7a, a series of wear tests were conducted. Figure $7 \mathrm{~b}$ shown the wear-test result corresponding to 100 forging cycles. It can be seen that the optimal tempering temperature and holding time are also $550{ }^{\circ} \mathrm{C}$ and $4 \mathrm{~h}$ respectively, and the wear depth of wear-resistance plate, $0.00987 \mathrm{~mm}$, is minimum, comparing it to that corresponding to all the PWHT conditions. The wear test results show a close agreement with the wear calculation result. 


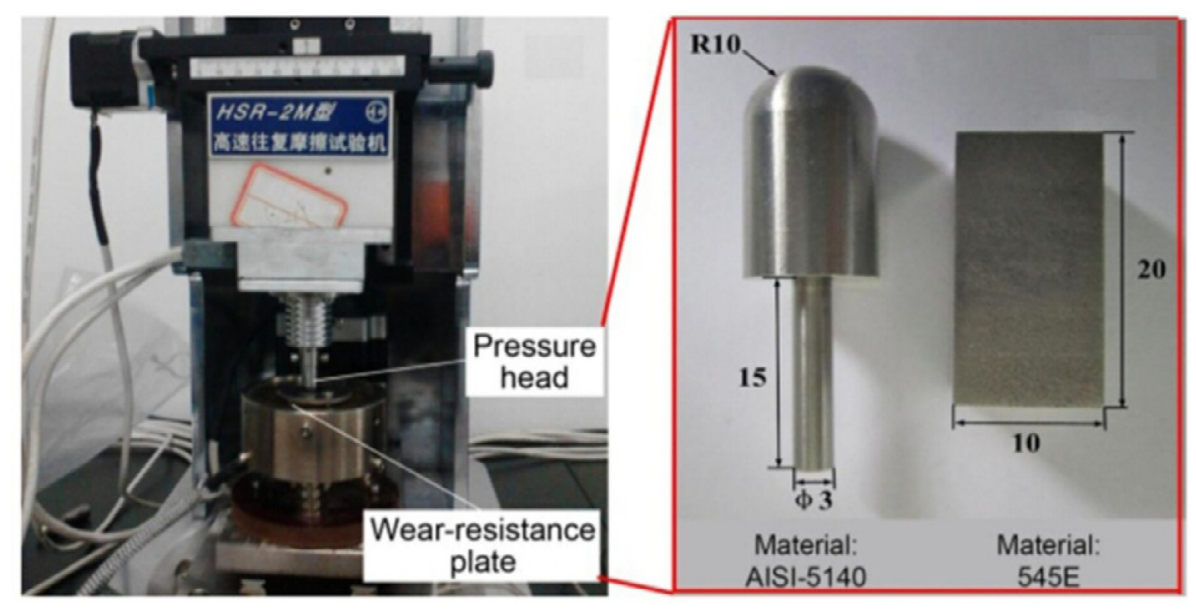

Figure 6. The HSR-2M wear-test machine and the friction pairs used in the wear test
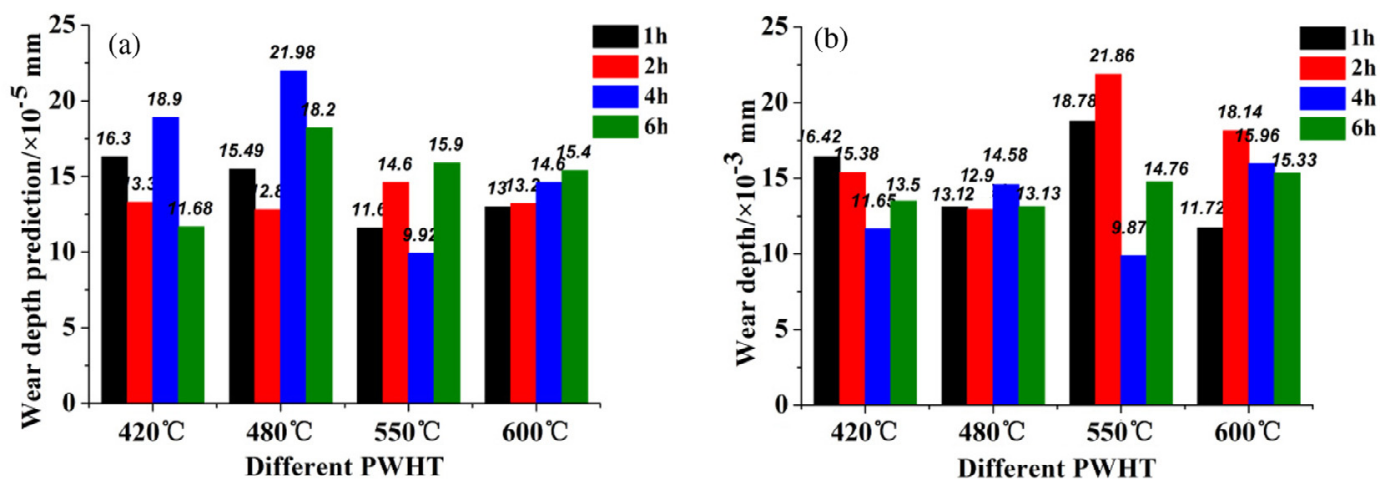

Figure 7. (a) Computed wear-depths for different PWHT conditions (single cycle simulation); (b) measured wear depths (after 100 forging cycles).

\subsection{Forging of the crankshaft}

In order to further verify FE simulation results, a serious of preparatory work was carried out. Firstly, surfacing welding was performed on a hot-forging cast-steel die, and the surfacing welding parameters were mentioned in the section of the die material used. After the weld surfacing, the cast-steel die was air cooled to about $300{ }^{\circ} \mathrm{C}$. Then a post-welding heat treatment was carried out on the die for stress relief (corresponding to an optimal condition, i.e. tempering temperature $550{ }^{\circ} \mathrm{C}$, holding time $4 \mathrm{~h}$ ). These will then be followed by crankshaft forging. A 6300T hot forging press was used for the forging of the crankshafts.

After 10,390 forging cycles, the die cavity was examined using an CMM machine. Figure 8a is the point cloud of the worn surfacing layer, and the Figure $8 \mathrm{~b}$ shows a comparison between the point cloud tested and the designed model of the finish forging die, from which the wear depth of surfacing layer of the die can be obtained. Figure 8c illustrates the finish forging die which is coated with surfacing layer. Comparison of the die wear depth at the section A-A between the simulation result and forging is illustrated in Figure 8d, which shows a good agreement with each other. It indicates the FEM simulation of the hot forging die wear is valid.

\section{Wear mechanism and strengthening mechanism}

\subsection{SEM observation and wear mechanism}

In order to gain insight into the wear mechanism, the wear debris were examined using SEM. The wear debris images corresponding to the optimal PWHT are illustrated in Figure 9. SEM examinations identified that there are three main types of wear during the forging process, i.e. abrasive wear, adhesive wear and oxidative wear. The adhesive wear debris corresponded to a rough surface, an uneven thickness and little oxygen. The shape of abrasive wear debris is banded. The oxidative wear debris corresponded to a smooth surface, an even thickness, and they contain a lot of oxygen. The proportion of the three types of wear debris was calculated using MATLAB, and it can be seen that the proportion of oxidative wear debris increases gradually as the holding time increases. 
(a)

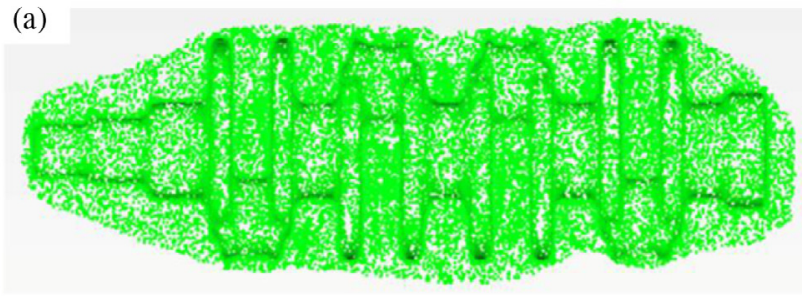

(c)

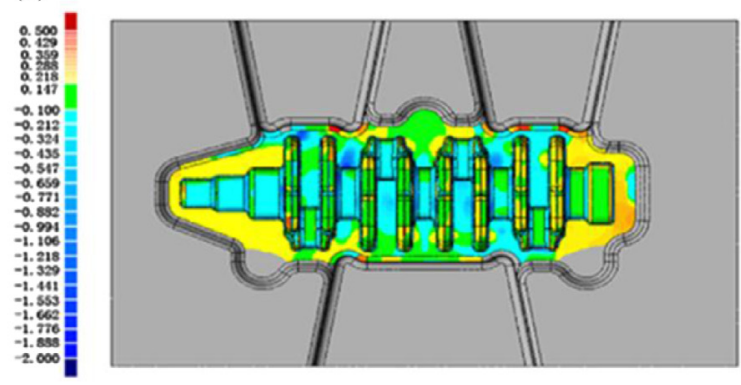

(b)

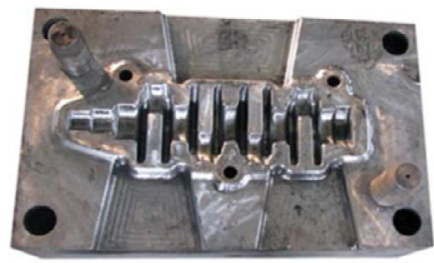

(d)

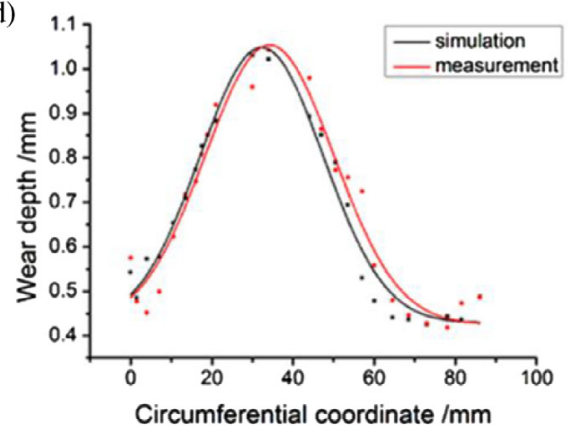

Figure 8. (a) The point cloud of the worn surfacing layer, (b) comparison of the point cloud tested and the design model of finish forging die, (c) finish forging die coated with surfacing layer and (d) comparison of the die wear depth at section A-A between simulation and the practical production.
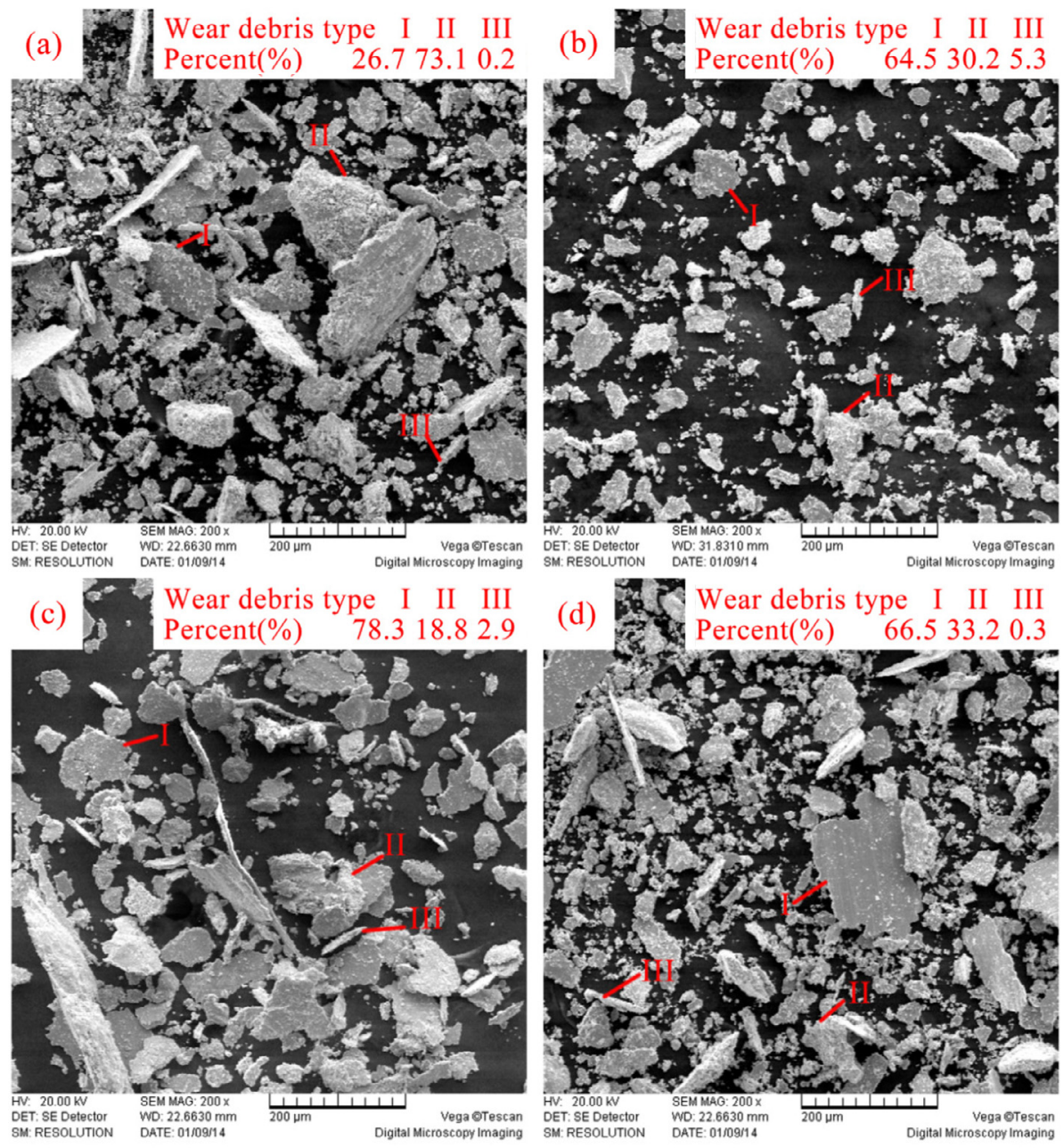

I-Oxidative wear debris II-Adhesive wear debris III-Abrasive wear debris

Figure 9. SEM images of wear debris when tempering temperature was $550{ }^{\circ} \mathrm{C}$ and holding time of: (a) $1 \mathrm{~h}$, (b) $2 \mathrm{~h}$, (c) $4 \mathrm{~h}$ and (d) $6 \mathrm{~h}$. 

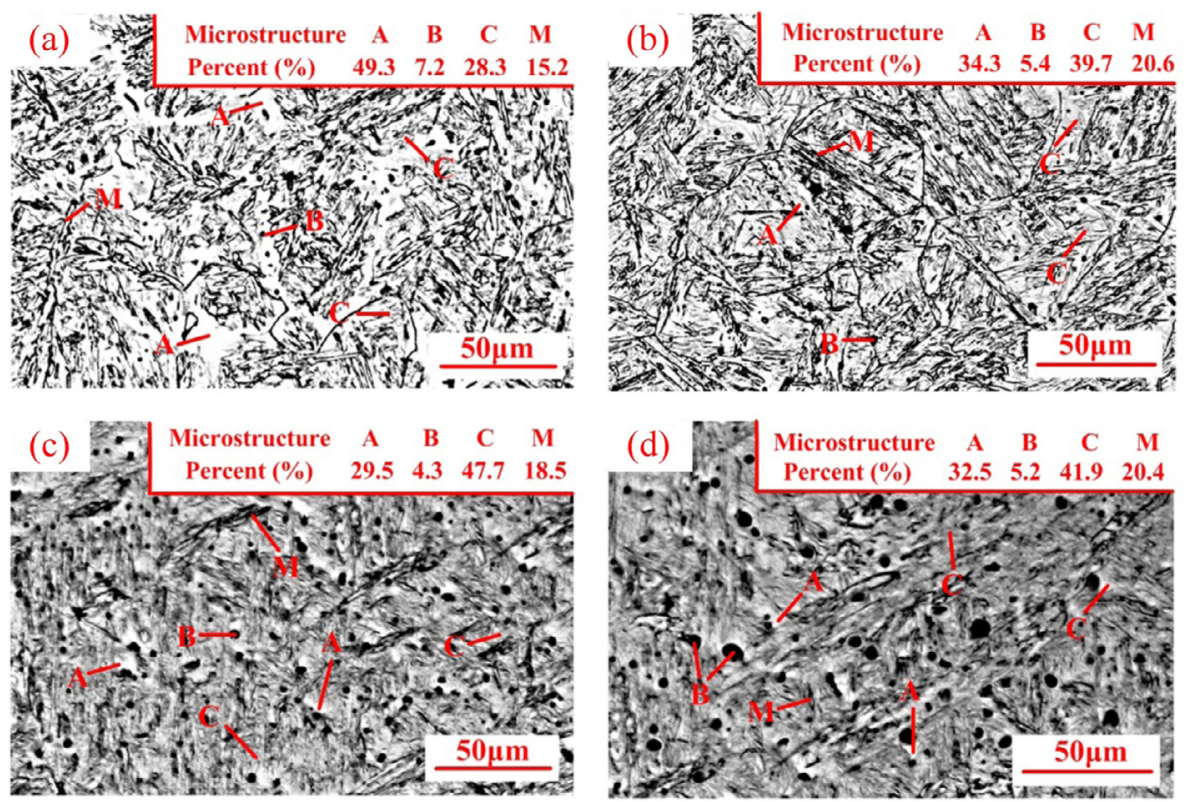

A-Retained Austenite B-Lower Bainite

C-Alloy Carbide M-Tempered Marensite

Figure 10. Microstructure of the surfacing layer with the tempering temperature is $550{ }^{\circ} \mathrm{C}$ and holding time of: (a) $1 \mathrm{~h}$, (b) $2 \mathrm{~h}$, (c) $4 \mathrm{~h}$ and (d) $6 \mathrm{~h}$.

Therefore, oxidative wear mechanism plays a dominant role among all the wear mechanisms.

\subsection{Microstructure investigation and strengthening mechanism}

To understand the mechanism of strengthening due to PWHT on the wear resistance of the surfacing layer, the microstructure investigations were conducted. Specimens from the surfacing layers were etched with $4 \%$ nitric acid solution for $15 \mathrm{~s}$. Then, a quantitative metallographic analysis system

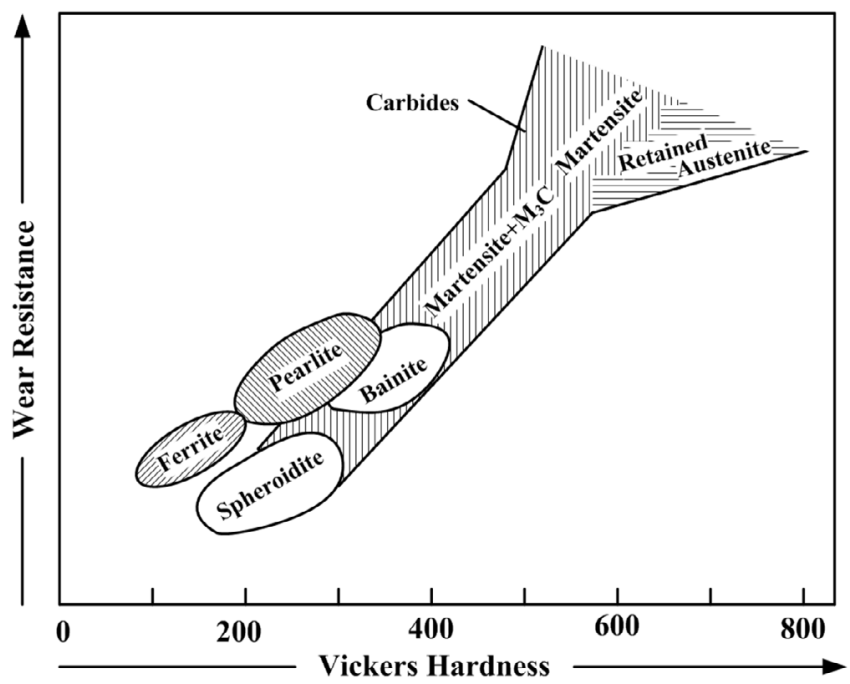

Figure 11. The influence of microstructures on wear resistance. was used to calculate the percentage of microstructures and the result can be seen in Figure 10.

It can be seen from Figure 10a that the microstructure of the surfacing layer is composed of tempered martensite, lower bainite, retained austenite and few undissolved alloy carbide when the tempering temperature was $550{ }^{\circ} \mathrm{C}$ and holding time $1 \mathrm{~h}$. When the tempering temperature was kept as $550{ }^{\circ} \mathrm{C}$ and the holding time extended to $2 \mathrm{~h}$, the retained austenite dissolved partly and the alloy carbide precipitation slightly increased, shown in Figure 10b. It is obvious, as shown in Figure 10c, that the retained austenite transformed almost completely and the alloy carbide was dispersively distributed in the metallographic structure when the holding time was $4 \mathrm{~h}$, which is closely related to the wear resistance improvement of the surfacing layer. While the holding time was prolonged to $6 \mathrm{~h}$, the alloy carbide decreased, as illustrated in Figure 10d. The decrease in dispersivity of alloy carbide resulted in the reduced wear-resistance of the surfacing layer, comparing to that with holding time of $4 \mathrm{~h}$. Glaeser [12] studied the relative wear resistance of different microstructures for steel, from which it can be known that the wear resistance of alloy carbide is better when it dispersively distributes in the metallographic structure. The study reported in this paper, once again, confirms such a finding.

\section{Conclusions}

For large hot forging, replacing a single piece die made of the hot working steel with the die construction consisting of casting-steel substrate coated with surfacing layer is beneficial, in terms of reducing the die cost and prolonging the service life of the die. The study reported in this paper is focused on the 
effect of Post Welding Heat Treatments (PWHT) on the wear resistance of the surfacing layer, based on which the following conclusions are drawn:

1. The FE results showed that wear depth of the surfacing layer is determined significantly by the PWHT, and the optimal tempering temperature and holding time are $550{ }^{\circ} \mathrm{C}$ and $4 \mathrm{~h}$ respectively. The wear test and forging test results show a good agreement with the FE simulation.

2. Similar to normal hot-forging dies, SEM examinations identified three main types of wear debris existing when a surfacing layer structure was used for the die, and the oxidative wear debris were dominant.

3. Microstructure investigations on the surfacing layer with different PWHT conditions showed that the alloy carbide dispersively distributing in the metallographic structure could improve the wear resistance of the surfacing layer effectively, when the tempering temperature and holding time are $550{ }^{\circ} \mathrm{C}$ and $4 \mathrm{~h}$ respectively.

Acknowledgements. This study was financially supported by the National Natural Science Foundation of China through a funded project (No. 51275543) and the Fundamental Research Funds for the Central Universities of China (No. CDJZR14130005 and No. CDJZR13130087).

\section{References}

1. K. Lange, L. Cesr, M. Geiger, Crip. Ann-manuf. Techn. 41 (1992) 667-675.

2. L. Dobrzanski, M. Polok, J. Mater. Process. Technol. 155 (2004) 1995-2001.

3. L. Dobrzanski, D. Pakula, A. Křiž, J. Mater. Process. Technol. 175 (2006) 179-185.

4. K.T. Rie, A. Gebauer, J. Wöhle, Surf. Coat. Technol. 74 (1995) 375-381.

5. H. Hoche, J. Schmit, Surf. Coat. Technol. 205 (2011) 145-150.

6. V. Birman, L.W. Byrd, Appl. Mech. Rev. 60 (2007) 195-216.

7. J.F. Archard, J. Appl. Phys. 24 (1953) 981-988.

8. B. Painter, R. Shivpuri, T. Altan, J. Mater. Process. Technol. 59 (1996) 132-143.

9. B.A. Behrens, F. Schaefer, J. Mater. Process. Technol. 167 (2005) 309-315.

10. D.H. Kim, B.M. Kim, C.G. Kang, Finite. Elem. Anal. Des. 41 (2005) 1225-1269.

11. S. Abachi, M. Akkok, I.M. Gokler, Tribol. Int. 43 (2010) 467-473.

12. W.A. Glaeser, Materials for Tribology, Elsevier Science Ltd, Amsterdam, The Netherlands, 1992.

Cite this article as: Xu W, Ma X, Tang N, Zhu L, Li W \& Ding Y: Effect of post-welding heat treatment on wear resistance of cast-steel die with surfacing layer. Manufacturing Rev. 2015, 2, 25. 